\title{
Analisis Penyebab Kerugian Pada PT Sumber Alfaria Trijaya Tbk Cabang Manado
}

\author{
SITI ASMIANTI ${ }^{1}$, GRACE NANGOI ${ }^{2}$, JESSY WARONGAN ${ }^{3}$ \\ ${ }^{1,2,3}$ Program Magister Akuntansi, Fakultas Ekonomi dan Bisnis Universitas Sam Ratulangi \\ email: sitiasmianti@yahoo.com¹, gracebn@yahoo.com², jdimarcus@gmail.com ${ }^{3}$
}

\begin{abstract}
This study aims to analyze the causes of losses at PT Sumber Alfaria Trijaya Tbk Branch Manado. This study was using qualitative method with case study approach. Data were obtained through in-depth interview technique, documentation study and observation. Key informants were determined by using purposive sampling that they meet the criteria set out to obtain accurate and precise information. Triangulation techniques were used to test the validity of data and data sources. The transcript data described from the interview results were analyzed using analytical methods consisting of the giving of themes/coding, conceptualizing scientific statements and interpreting them in a narrative form. The result of this research shows that there were 6 (six) causes of losses at PT Sumber Alfaria Trijaya Tbk Branch Manado, there were expansion, age of the company, fraud, insufficient internal control, human resource competency, and business competition among industries. The efforts made are reward and punishment strategies, improvement of human resources, and increasing sales by increasing franchise stores. Recommendations are to improve compliance, attitudes and responsibilities of employees for the work given to them, to improve the commitment of leaders to be more assertive and to improve supervision and internal control in order to enhance employee integrity to reduce the potential of fraud.
\end{abstract}

Keywords: Retail, Compliance, Internal Control, Fraud

Abstrak. Penelitian ini bertujuan untuk menganalisis penyebab kerugian pada PT Sumber Alfaria Trijaya Tbk Cabang Manado. Penelitian ini adalah penelitian kualitatif dengan pendekatan studi kasus. Data diperoleh melalui teknik wawancara mendalam, observasi dan studi dokumentasi. Informan kunci ditetapkan secara purposive sampling dengan syarat memenuhi kriteria yang ditetapkan untuk mendapatkan informasi yang tepat dan akurat. Teknik triangulasi digunakan untuk menguji validitas data dan sumber data. Data transkrip yang diuraikan dari hasil wawancara dianalisis menggunakan metode analisis yang terdiri dari pemberian tema/coding, konseptualisasi pernyataan ilmiah dan menginterpretasikannya dalam bentuk narasi. Hasil penelitian menunjukkan bahwa terdapat 6 (enam) penyebab kerugian pada PT Sumber Alfaria Trijaya Tbk Cabang Manado, yaitu ekspansi, umur perusahaan, adanya fraud, pengendalian internal yang kurang memadai, kompetensi sumber daya manusia, serta persaingan usaha sesama industri. Upaya yang dilakukan yaitu adanya strategi reward dan punishment, perbaikan sumber daya manusia, serta meningkatkan penjualan dengan memperbanyak toko franchise. Saran yang diberikan adalah perlu adanya perbaikan dalam hal kepatuhan, sikap dan tanggung jawab karyawan terhadap pekerjaan yang diberikan, perlu memperbaiki komitmen pimpinan agar lebih tegas dan meningkatkan pengawasan serta pengendalian internal yang lebih terkontrol dalam hal meningkatkan integritas karyawan untuk mengurangi adanya potensi fraud.

Kata Kunci: Ritel, Kepatuhan, Pengendalian Internal, Fraud.

\section{Pendahuluan}

Era globalisasi saat ini, semakin memudahkan dalam perolehan informasi dari seluruh perusahaan go public. Salah satu infomasi yang paling penting dari perusahaan go public adalah laporan keuangan. Penerbitan laporan keuangan secara umum bertujuan untuk memberikan informasi mengenai posisi keuangan, kinerja dan arus kas perusahaan. Menurut Pernyataan Standar Akuntansi Keuangan Nomor (No) 1 menyatakan bahwa laporan keuangan merupakan bagian dari proses pelaporan keuangan. Laporan keuangan yang lengkap biasanya meliputi neraca, laporan laba rugi, laporan perubahan posisi keuangan (yang dapat disajikan dalam berbagai cara misalnya, sebagai laporan arus kas, atau laporan arus dana), catatan dan laporan lain serta materi penjelasan yang merupakan bagian integral dari laporan keuangan. Disamping itu juga termasuk skedul dan informasi tambahan yang berkaitan dengan laporan tersebut misalnya, informasi keuangan segmen industri dan geografis serta pengungkapan pengaruh perubahan harga.

Informasi yang dihasilkan laporan keuangan akan sangat bermanfaat bagi pengguna laporan keuangan apabila informasi tersebut relevan dan bermanfaat untuk pengambilan keputusan. Informasi yang tersaji dalam laporan keuangan pada hakekatnya menyajikan keterangan, catatan atau gambaran untuk keadaan masa sekarang dan masa lalu. Salah satu informasi laporan keuangan yang dapat menunjukan kinerja perusahaan adalah laporan laba rugi. Informasi yang terdapat di dalam laporan 
laba rugi dianggap memiliki manfaat dalam pengambilan keputusan keuangan. Tujuan utama perusahaan adalah memaksimalkan laba. Laba merupakan indikator prestasi atau kinerja perusahaan yang tampak di laporan keuangan, tepatnya laba rugi. Pada dasarnya tujuan laporan laba rugi yaitu menilai kinerja perusahaan, hal tersebut dapat dilihat dari jumlah laba atau rugi yang diperoleh perusahaan.

Di sisi lain perusahaan menekan biaya sekecil mungkin sehingga konsep efisiensi tercapai. Jika pendapatan diperoleh secara maksimal dan biaya yang dikeluarkan seminimal mungkin, maka akan tercapai laba yang maksimal. Oleh karena itu, tingkat profitabilitas dan kemampuan untuk mendapatkan profit adalah barometer keberhasilan suatu perusahaan. Perubahan dalam tingkat profitabilitas merupakan indikasi dari keberhasilan atau sebaliknya. Profit dalam konteks ini dipahami sebagai pendapatan yang merupakan kelebihan dari semua biaya yang timbul atas semua input yang dibutuhkan dalam proses produksi (Grant, 1995 dalam Heikal dan Ummah, 2014).

Semakin berkembangnya dunia usaha saat ini, persaingan antar perusahaan khususnya antar perusahaan yang sejenis akan semakin ketat, oleh karena itu agar perusahaan dapat tumbuh dan berkembang, perusahaan harus mencermati kondisi dan kinerja perusahaan. Perusahaan akan melakukan berbagai aktivitas untuk mencapai tujuannya yaitu memperoleh keuntungan, menjaga kelangsungan hidup, dan menjalani pertumbuhan. Untuk menjaga kelangsungan hidup perusahaan, dibutuhkan suatu pengelolaan sumber daya yang dilakukan oleh pihak manajemen. Pihak manajemen harus mengkoordinasikan penggunaan seluruh sumber daya yang dimiliki oleh perusahaan secara efisien dan efektif. Efisien berkenaan dengan biaya yang seminimal mungkin untuk mencapai tujuan tersebut, sedangkan efektif berkaitan dengan tujuan yang hendak dicapai (Martono dan Harjito, 2010:2).

Salah satu fungsi keberhasilan yang penting bagi keberhasilan perusahaan dalam pencapaian tujuannya adalah kondisi manajemen keuangan perusahaan tersebut. Oleh karena itu perusahaan harus memberi perhatian khusus terhadap kemajuan keuangan demi tercapainya tujuan perusahaan. Menurut Riyanto (2010:4) manajemen keuangan sebagai keseluruhan aktivitas perusahaan yang bersangkutan dengan usaha mendapatkan dana yang diperlukan dengan biaya yang minimal dan syarat-syarat yang paling menguntungkan serta menggunakan dana tersebut seefisen mungkin. Manajer keuangan perlu mengambil keputusan-keputusan yang benar dalam penentuan tujuan perusahaan serta dalam usaha pencapaian tujuan tersebut. Keputusan yang diambil haruslah dengan prinsip memaksimumkan nilai perusahaan, yang identik dengan memaksimumkan laba, serta meminimumkan tingkat resiko.

Bisnis ritel saat ini berkembang dengan pesat dan memberikan peluang bagi pengelola untuk mendapatkan profit dengan tingkat yang besar. Peritel dalam upaya mengembangkan bisnis yang dimiliki hendaknya berupaya secara terus menerus untuk meningkatkan kemampuan yang dimiliki dalam rangka meminimalisasi risiko yang dihadapi. Pemahaman yang dilakukan diharapkan dapat menjadi informasi penting dalam rangka melakukan evaluasi terhadap hal-hal yang harus dilakukan guna mengantisipasi risiko yang terjadi. Peritel memiliki dua kriteria risiko yaitu risiko dari luar dan dalam usaha yang dimiliki. Risiko yang berasal dari luar usaha umumnya disebabkan oleh keberadaan peritel dalam suatu lingkungan usaha dan berinteraksi dengan banyak pihak, sehingga perilaku dari pihak-pihak yang melakukan interaksi tersebut akan mendatangkan risiko bagi peritel. Risiko yang berasal dari dalam usaha umumnya disebabkan oleh tantangan bagi peritel dalam melakukan pengambilan keputusan untuk memajukan usaha yang dimiliki, khususnya upaya untuk mengelola karyawan.

Pengelolaan yang baik terhadap karyawan diharapkan mampu menekan risiko dari dalam usaha ritel yang dimiliki, karena karyawan adalah adalah inti dari bisnis ritel. Keberhasilan pengelolaan terhadap sumber daya yang dimiliki sangat tergantung dari kemampuan karyawan untuk menggunakan sumber daya yang dimiliki sesuai tujuan yang diharapkan. Karyawan adalah penggerak bagi sumber daya lainnya yang dimiliki oleh peritel. Bila karyawan tidak mampu menggunakan sumber daya yang dimiliki, maka sumber daya yang lain tidak mampu digunakan dengan maksimal. Kondisi yang ada menuntut adanya kemampuan dari peritel untuk melakukan manajemen sumber daya manusia terhadap karyawan yang dimiliki. Dari sekian banyak kejahatan yang dilakukan karyawan dalam bekerja, bentuk yang paling banyak ditemukan adalah kejahatan internal yang dilakukan oleh karyawan sendiri, karena pada umumnya telah mengerti cara kerja dan sistem pengamanan barang di toko atau perusahaan yang bersangkutan (Wimbush dan Dalton, 1997).

Industri ritel merupakan salah satu industri strategis di Indonesia. Industri ini memberikan sumbangsih terbesar kedua dalam Produk Domestik Bruto (PDB) dari tahun ke tahun setelah industri pengolahan. Industri ini juga mampu menyerap banyak tenaga kerja. Berdasarkan Asosiasi Perusahaan 
Ritel Indonesia (Aprindo) yang dikutip pada position paper Komisi Pengawas Persaingan Usaha (KPPU) Indonesia mengungkapkan bahwa sektor ritel berhasil menyerap 18,9 juta tenaga kerja atau menempati urutan kedua setelah sektor pertanian yang mampu menyerap 41,8 juta orang. Penyerapan tenaga kerja yang besar menyebabkan berkurangnya pengangguran di Indonesia.

Selain itu, peran penting industri ritel dapat dilihat melalui proses distribusi. Industri ritel merupakan distributor antara produsen dengan konsumen. Berbagai produk dan jasa yang diproduksi oleh produsen disalurkan melalui industri ini. Masyarakat sebagai konsumen terasa terbantu dengan kehadiran gerai ritel. Di satu sisi, produsen terbantu karena produk yang mereka produksi dapat disalurkan kepada konsumennya dan di sisi lain, konsumen juga terbantu karena mereka dapat menjangkau kebutuhan sehari-hari melalui gerai ritel. Kebijakan pemerintah akan keberadaan industri ritel yang memberikan kemudahan terhadap investor lokal maupun asing mengakibatkan industri ini semakin menjanjikan. Dasar hukum yang menjadi acuan para peretail selama ini adalah Peraturan Presiden No. 112 Tahun 2007 tentang Penataan dan Pembinaan Pasar Tradisional, Pusat Perbelanjaan dan Toko Modern yang secara operasionalnya diatur dalam Peraturan Menteri Perdagangan No. 53 Tahun 2008 tentang Pedoman Penataan dan Pembinaan Pasar Tradisional, Pusat Perbelanjaan dan Toko Modern.

Pada tahun 2017 terjadi fenomena ditutupnya beberapa minimarket dan department store. Berdasarkan data melalui Asosiasi Pengusaha Ritel Indonesia (Aprindo), Ketua Umum Aprindo Roy Nicholas Mandey mengatakan industri ritel melamban sejak periode 2012-2013. Adapun, pada tahun 2017 industri ritel di Indonesia terus mengalami penurunan. Aprindo mengakui penjualan ritel pada kuartal pertama tahun 2017 mengalami penurunan yang cukup signifikan. Tercatat, pertumbuhan penjualan industri ritel menurun drastis sebesar 20 persen menjadi Rp30 triliun sepanjang kuartal I di tahun 2017 dibandingkan dengan tahun 2016 di kuartal yang sama yang mencapai Rp 40 triliun (Prayogo, 2017). Realisasi pertumbuhan di 2017 jauh lebih rendah jika dibandingkan tahun-tahun sebelumnya yang selalu mencapai dua digit alias sekitar 10-14\%. Sementara penjualan ritel yang dicatat oleh Aprindo hingga akhir tahun hanya tumbuh sekitar 7-8\% (Kusuma, 2017).

PT Sumber Alfaria Trijaya Tbk atau Alfamart adalah jaringan minimarket bahan pokok seharihari di Indonesia, dengan kualitas tinggi namun tetap terjangkau. Kemajuan Alfamart yang pesat saat ini ditentukan oleh strategi pihak manajemen Alfamart yang tepat dan unik. Pada tahun 2014, Alfamart mulai masuk dan berkembang di Manado. Banyaknya perusahaan ritel yang terdapat di Manado, menjadikan Alfamart harus mampu bersaing secara sehat agar mampu menarik para konsumen dan mendapat kepercayaan dari para konsumen. Apabila hal ini tercapai, maka perusahaan akan mendapatkan loyalitas dari konsumennya, yang akan berujung pada kenaikan penjualan, serta dapat memperoleh laba yang diinginkan perusahaan. Pada tahun 2016, Alfamart pun mampu berkembang sampai ke Gorontalo. Namun pada kenyataannya, sejak Alfamart didirikan di Manado dan Gorontalo sampai pada tahun 2018, Alfamart terus mengalami kerugian. Fenomena kerugian ini merupakan sesuatu hal yang menarik untuk dikaji lebih lanjut. Berdasarkan studi pendahuluan (preliminary survey) yang dilakukan oleh peneliti, terdapat masalah-masalah pada PT Sumber Alfaria Trijaya Tbk Cabang Manado, seperti adanya penyimpangan di toko maupun di Back Office.

Berdasarkan data awal yang di dapat oleh peneliti, diperoleh hasil bahwa pada tahun 20162017 terdapat beberapa kasir toko yang melakukan fraud atau kecurangan dengan cara tidak menyetorkan hasil penjualan atau uang yang ada di kasir pada saat Jam Waktu Pengiriman (JWP). Jam waktu pengiriman ini merupakan jadwal bagi setiap toko untuk menyetorkan hasil penjualan atau uang yang ada di kasir toko. Selanjutnya tingginya angka barang dagangan yang hilang dan rusak yang terjadi di toko. Perusahaan ritel seperti Alfamart mempunyai persediaan barang dagang yang mudah hilang dan mudah rusak, dan setiap karyawan mempunyai kesempatan untuk melakukan kecurangan seperti pencurian persediaan. Kecurangan dalam perusahaan juga dapat terjadi karena adanya sistem pengendalian intern perusahaan yang kurang baik. Hal ini akan mengakibatkan munculnya biaya yang seharusnya tidak terjadi.

Berdasarkan laporan laba rugi perusahaan tahun 2016-2018, menunjukkan bahwa pada tahun 2016 kerugian terjadi sebesar Rp $(55,729,420,086)$, adapun pada tahun 2017 kerugian menjadi Rp $(81,905,749,335)$, sedangkan pada tahun 2018 sebesar Rp $(56,987,504,863)$. Gross profit pada tahun 2016 adalah 18\%, tahun 2017 adalah 17\%, dan pada tahun 2018 menjadi 18\%. Berdasarkan data tersebut dapat dilihat bahwa kerugian disebabkan oleh meningkatnya beban pada setiap tahun, sedangkan pendapatan yang dihasilkan tidak sebanding dengan pengeluaran atau beban yang dikeluarkan perusahaan. 
Tujuan penelitian ini untuk: 1) menganalisis penyebab kerugian pada PT Sumber Alfaria Trijaya Tbk Cabang Manado; 2) menganalisis upaya yang dilakukan PT Sumber Alfaria Trijaya Tbk Cabang Manado sehingga tidak mengalami kerugian.

\section{Model Analisis}

Model analisis pada penelitian ini dimulai dengan melihat fenomena kerugian yang terjadi pada PT Sumber Alfaria Trijaya Tbk dan menentukan topik penelitian. Selanjutnya melakukan pengumpulan data dengan teknik wawancara dan didukung dengan studi dokumentasi dan observasi. Langkah berikutnya yaitu mengolah data, menguji keabsahan data dan menyusun laporan hasil penelitian.

Gambar 1. Model Analisis

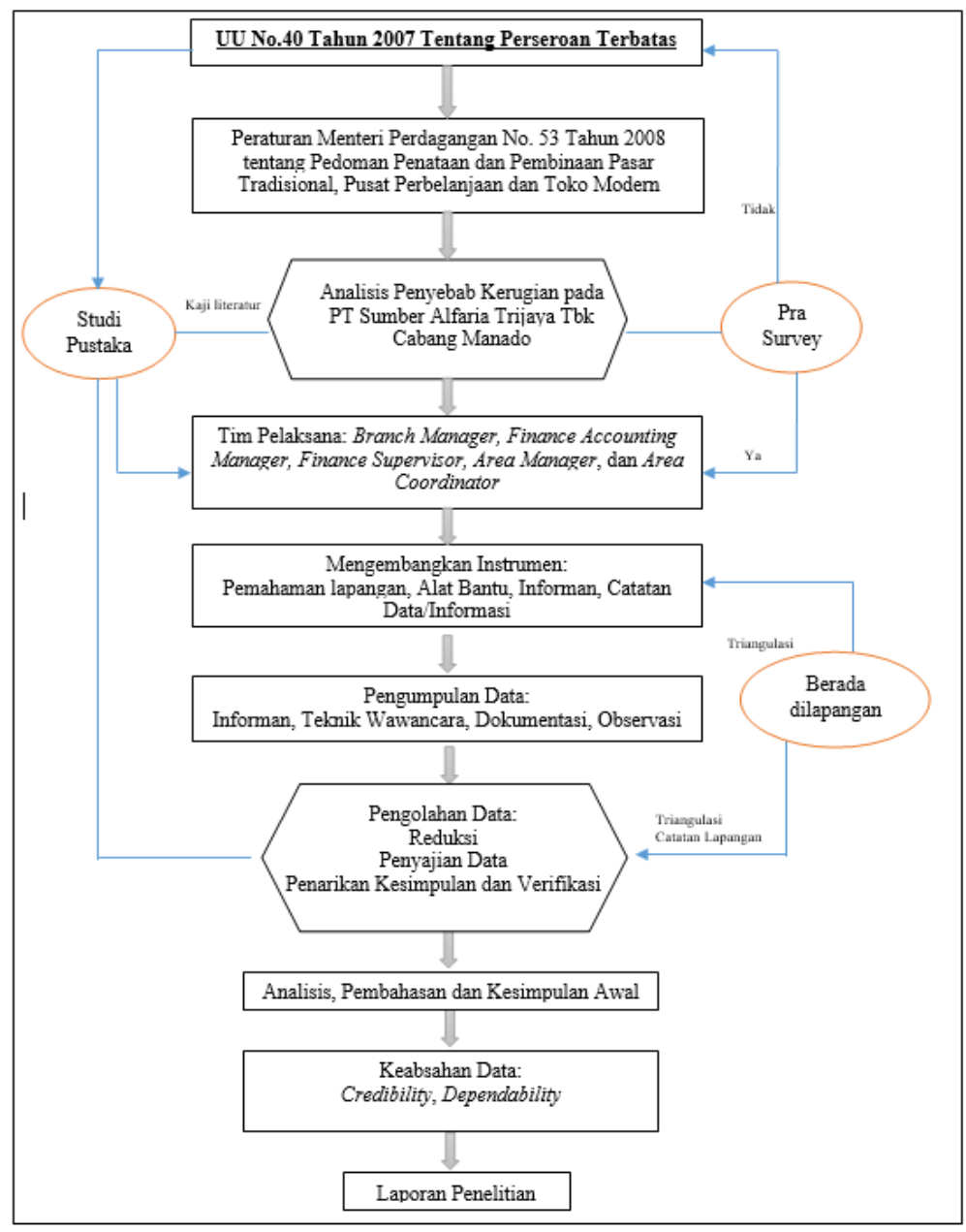

\section{Metode Penelitian}

Penelitian ini menggunakan metode pendekatan kualitatif untuk mengeksplorasi dan memahami makna yang oleh sejumlah individu atau sekelompok orang dianggap berasal dari masalah sosial atau kemanusiaan (Creswell, 2010). Penelitian ini menggunakan pendekatan metode studi kasus yang menurut Creswell (2010) merupakan strategi penelitian dimana didalamnya peneliti menyelidiki secara cermat suatu program, peristiwa, aktivitas, proses, atau sekelompok individu. Endraswara (2013:78) menyatakan bahwa studi kasus dibagi menjadi dua golongan, yaitu studi kasus berupa penyimpangan dari kewajaran dan studi kasus ke arah perkembangan yang positif. Penelitian ini termasuk dalam golongan studi kasus yang berupa penyimpangan dari kewajaran karena adanya temuan berupa fraud, sehingga akan diteliti apakah temuan tersebut dapat menyebabkan kerugian perusahaan, serta berusaha menemukan tindak lanjut berupa upaya perbaikan yang perlu dilakukan untuk mengatasi kerugian perusahaan.

Teknik pengumpulan data yang dilakukan dalam penelitian ini adalah wawancara, studi dokumentasi dan observasi atau gabungan ketiganya yang disebut triangulasi. Informan kunci 
ditetapkan secara purposive sampling dengan syarat memenuhi kriteria yang ditetapkan untuk mendapatkan informasi yang tepat dan akurat. Teknik analisis data yang digunakan dalam penelitian ini adalah teknik analisis Model Milles dan Huberman dalam Sugiyono (2015:85) yang terdiri atas data reduction, data display dan drawing conclusion/verification yang dilakukan secara interaktif dan berlangsung secara terus menerus sampai tuntas, sehingga datanya mencapai jenuh. Uji keabsahan data yang digunakan dalam penelitian ini meliputi uji validitas internal (credibility) dengan memanfaatkan triangulasi yang terdiri dari triangulasi sumber dan triangulasi teknik dan uji reliabilitas (dependability) yang dilakukan oleh pembimbing mulai dari memeriksa keseluruhan aktifitas penelitian, mulai dari menentukan masalah/ fokus, menentukan sumber data, menentukan analisis data, melakukan uji keabsahan data dan sampai pada pembuatan kesimpulan/ laporan akhir.

\section{Analisis dan Pembahasan}

Penelitian dilakukan selama 8 (delapan) bulan sejak bulan Juli 2018 sampai Februari 2019 dengan melakukan wawancara sesuai dengan pedoman wawancara kepada informan dengan menggunakan alat perekam untuk merekam seluruh isi wawancara, serta menggunakan instrumen pendukung antara lain buku catatan, alat perekam berupa audio, kamera untuk mendokumentasikan kegiatan di lapangan, dan laptop untuk mengetik hasil penelitian dan rekaman wawancara sehingga berbentuk transkrip wawancara.

\section{Penyebab Kerugian Pada PT Sumber Alfaria Trijaya Tbk Cabang Manado}

Terdapat 6 (enam) penyebab yang ditemukan dalam menganalisis penyebab kerugian yaitu: 1) ekspansi; 2) umur perusahaan; 3) fraud; 4) pengendalian internal yang belum memadai; 5) kompetensi sumber daya manusia serta 6) persaingan usaha sesama industri.

Penyebab pertama yaitu perusahaan masih melakukan ekspansi. Alfamart mengalami kerugian karena jumlah pendapatannya masih kecil, jika dibandingkan dengan biayanya. Biaya tiap bulannya bisa mencapai dua kali lipat dari pendapatan yang dihasilkan. Adanya ekspansi dan pembukaan Branch yang baru sehingga biaya yang dikeluarkan lebih besar daripada penghasilan-penghasilan yang dilakukan melalui penjualan di toko. Terdapat dua klasifikasi beban pada PT Sumber Alfaria Trijaya Tbk, yaitu beban penjualan dan beban umum dan administrasi. Biaya terbesar yang ada adalah biaya gaji, biaya listrik, sewa gedung, peralatan inventaris, perlengkapan kantor serta renovasi bangunan. Biaya-biaya inilah yang sangat dominan, dan sulit untuk dikurangi, karena beberapa biaya merupakan biaya yang kemungkinan akan terus naik biayanya setiap bulannya, seperti biaya yang menjadi penyebab kerugian yaitu adanya biaya sewa gedung yang lumayan besar dan penjualan di toko tidak cukup untuk menutupi biaya sewa gedung tersebut, sehingga perusahaan harus meningkatkan lagi penjualannya agar bisa menutupi beban-beban yang ada dalam perusahaan. Menurut SFAC No. 5 pengertian losses adalah habisnya nilai yang tidak berhubungan dengan operasi- operasi normal perusahaan disetiap periode, tetapi yang berasal dari kegiatan- kegiatan luar yang tidak berulang kembali dan tidak diantisipasikan. Sebab apabila dapat diantisipasikan, losses ini seharusnya bisa dicegah. Apabila expiration ini merupakan koreksi- koreksi expense tahun lalu, maka ini harus dicatat sebagai koreksi tahun- tahun yang lalu dan bukan sebagai losses. Ekspansi perusahaan umumnya dipandang sebagai salah satu indikator keberhasilan atau kemajuan sebuah perusahaan atau anak perusahaan. Ekspansi perusahaan biasanya ditandai dengan seringnya perusahaan mengambil proyekproyek yang bersifat jangka panjang. Namun, ekspansi perusahaan membutuhkan dana yang tidak sedikit, sehingga untuk melakukan ekspansi, perusahaan harus berusaha keras dalam mencari sumber pendanaan yang mudah dan tidak terlalu membebani perusahaan. PT Sumber Alfaria Trijaya Tbk melakukan ekspansi dengan cara meluaskan usahanya ke daerah-daerah pelosok yang dirasa membutuhkan adanya minimarket untuk memenuhi kebutuhan masyarkat sekitarnya. Perluasan atau ekspansi bisnis diperlukan oleh suatu perusahaan untuk mencapai efisiensi, menjadi lebih kompetitif, serta untuk meningkatkan keuntungan atau profit perusahaan. Dijalankannya ekspansi oleh suatu perusahaan dapat memperbesar kemungkinan untuk dapat memperoleh keuntungan-keuntungan ekonomis seperti adanya produksi yang ekonomis, pembelian dan penjualan yang ekonomis, manajemen yang ekonomis, serta pembelanjaan yang ekonomis (Riyanto, 2010 : 232).

Penyebab kedua yaitu umur perusahaan. Umur perusahaan adalah lamanya sebuah perusahaan berdiri, berkembang dan bertahan. Umur perusahaan dihitung sejak perusahaan tersebut berdiri berdasarkan akta pendirian sampai penelitian dilakukan. Perusahaan yang sudah lama berdiri, kemungkinan sudah banyak pengalaman yang diperoleh. Semakin lama umur perusahaan, semakin banyak informasi yang telah diperoleh masyarakat tentang perusahaan, dan hal ini akan menimbulkan 
kepercayaan konsumen terhadap produk-produk yang ditawarkan oleh perusahaan tersebut. Umur perusahaan merupakan hal yang dipertimbangkan investor dalam menanamkan modalnya.Umur perusahaan mencerminkan perusahaan tetap survive dan menjadi bukti bahwa perusahaan mampu bersaing dan dapat mengambil kesempatan bisnis yang ada dalam perekonomian. Selain itu, perusahaan yang telah lama berdiri tentunya mempunyai strategi dan kiat-kiat yang lebih solid untuk tetap bisa survive dimasa depan. Semakin lama sebuah perusahaan berdiri, tentunya telah banyak pula mengalami lika-liku dalam berbisnis, mulai dari kemajuan hingga masalah dan kendala yang dihadapi. Kemampuan sebuah perusahaan untuk menyelesaikan berbagai masalah yang muncul dalam masa pengelolaan perusahaan, akan semakin menguatkan keberadaan perusahaan itu sendiri. Perusahaan yang telah lama berdiri umumnya memiliki profitabilitas yang lebih stabil dibandingkan perusahaan yang baru berdiri atau yang masih memiliki umur yang singkat. Alfamart merupakan cabang yang baru dan masih mengalami kesulitan-kesulitan dalam menjalankan usahanya, dan salah satu syarat perusahaan bisa untung juga dilihat dari usia branch itu sendiri. Pada penelitian ini, perusahaan masih dalam masa yang dikatakan sangat muda karena baru berusia empat tahun, sehingga biaya yang dikeluarkan masih besar untuk membiayai kegiatan operasional perusahaan. Perseroan memiliki umur yang tidak terbatas, sesuai dengan asumsi kesinambungan usaha/going concern, artinya umur perusahaan menunjukkan kemampuan perusahaan dalam mempertahankan kesinambungan usahanya (Harry, 2011: 4).

Penyebab ketiga yaitu fraud. Fraud atau kecurangan berupa penyalahgunaan wewenang oleh karyawan internal yang mengakibatkan kerugian perusahaan yang dilakukan oleh sejumlah karyawan yang tidak bertanggung jawab dengan menggunakan uang perusahaan. Ada pula karyawan toko yang melakukan cash out fiktif dan tidak menyetorkan uang sales penjualan toko, sehingga mengakibatkan adanya penyimpangan toko, yang pada akhirnya akan lebih menambah beban perusahaan jika tidak di selesaikan.Ketika bagian Inventory Control melakukan sidak ke toko-toko Alfamart, mereka biasanya akan menemukan banyaknya selisih barang antara penjualan dan sisa persediaan barang dagangan yang ada di toko. Selisih yang terjadi bisa plus ataupun mines. Selisih plus biasanya di toko ada mines on hand, jadi fisiknya lebih banyak daripada on hand. Biasanya karena ada barang kiriman dari DC, tapi dari karyawan di toko, mereka belum melakukan receipt terhadap kiriman barang tersebut, sehingga secara sistem terlihat bahwa fisiknya lebih banyak. Selisih mines berarti ada banyak barang hilang di toko. Hasil sidak yang dilakukan tersebut akan di rekap menjadi laporan nota selisih barang. Barang yang hilang tersebut akan menjadi tanggungan perusahaan sebesar 0,15\% untuk daerah Manado, dan $0,17 \%$ untuk daerah Gorontalo, dan sisanya akan di tanggung oleh karyawan toko dan harus dibayarkan melalui mekanisme potong gaji. Selanjutnya adanya pengaruh eksternal dari luar perusahaan, seperti lingkungan sosial (masyarakat dan pemerintah) yang kadang dapat mempengaruhi kegiatan usaha perusahaan dan terkadang mengakibatkan karyawan melakukan tindakan yang tidak sesuai dengan peraturan perusahaan dengan cara penyalahgunaan wewenang. Kondisi yang terjadi pada PT Sumber Alfaria Trijaya Tbk ini sesuai dengan teori yang di kemukanan oleh Albrecht et al. (2011) tentang gejala awal dari terjadinya fraud mengenai gejala kecurangan pada karyawan, biasanya gejala yang muncul dapat berupa pengeluaran financial tanpa dokumen pendukung, sering terjadi pencatatan yang salah/tidak akurat, bukti transaksi (dokumen sumber) seringkali tidak dapat diperlihatkan dengan alasan hilang. Fraud paling sulit dideteksi adalah korupsi, karena korupsi biasanya tidak dilakukan oleh satu orang saja tetapi sudah melibatkan pihak lain (kolusi). Kerjasama yang dimaksud dapat berupa penyalahgunaan wewenang, penyuapan, penerimaan hadiah yang illegal (gratuities) serta pemerasan secara ekonomis.

Penyebab keempat yaitu pengendalian internal yang belum memadai. Pengendalian internal tidak lepas dari adanya risiko-risiko yang akan muncul dan berpotensi untuk merugikan perusahaan di masa depan. Pengendalian internal harus diletakkan pada tempat yang mampu menunjukkan risikorisiko tersebut. Pengendalian internal yang buruk akan mengarahkan perusahaan kepada risiko kerugian, skandal, kegagalan, dan merusak reputasi perusahaan dalam sektor apapun perusahaan tersebut beroperasi. Pada bisnis ritel, pengendalian internal serta manajemen risiko sangat diperlukan karena bidang usaha ritel merupakan bidang usaha dengan tingkat aktivitas operasional yang sangat tinggi sehingga menuntut perusahaan untuk mengelola setiap risiko yang dihadapinya secara efektif agar terhindar dari kerugian secara finansial maupun penurunan brand image yang berdampak kepada going concern perusahaan. Pada umumnya bagi perusahaan ritel yang baru berkembang seperti Alfamart yang berada di Manado, perlunya kontrol dalam memantau kegiatan yang terjadi sehingga meminimkan terjadinya kecurangan yang dapat merugikan perusahaan. Kepala toko harus lebih memperhatikan kondisi yang ada di toko dan anak-anak tokonya agar menjalankan pekerjaannya 
dengan baik sehingga tidak terjadi penyimpangan toko, seperti rutin melakukan FIFO dan LIFO saat barang datang dan saat akan mendisplay barang dari Distribution Center (DC). Sistem pengendalian internal perlu diterapkan pada berbagai jenis usaha bisnis termasuk pada usaha bisnis ritel. Dilatar belakangi meningkatnya operasi perusahaan, volume kegiatan semakin meningkat, dan banyak pula permasalahan yang timbul dalam perusahaan serta perkembangan dunia usaha dalam persaingan saat ini. Oleh karena itu perusahaan perlu menetapkan sistem pengendalian yang dapat membantu dalam mengawasi kegiatan operasi perusahaan secara efektif dan efisien, agar perusahaan dapat bertahan dan mencapai tujuannya, tentunya apabila dikelola dengan baik dan mempunyai pengendalian internal yang baik. Pengendalian internal yang dimaksud merupakan sistem dan prosedur yang digunakan perusahaan untuk mencapai sasaran dan tujuan yang diinginkan. Sistem Pengendalian Internal juga merupakan suatu pengendalian atau pengawasan terhadap bagian-bagian terkait, analisis laporan dan kebijakan dalam perusahaan termasuk stuktur organisasi yang dilakukan secara berkelanjutan. Kegiatan pada sistem pengendalian internal dilakukan pada beberapa bagian yang terkait dengan fungsi pengendalian internal yang ada. Salah satu tujuan dari beberapa perusahaan yang pada umumnya bertujuan untuk menghasilkan laba yang optimal agar dapat mempertahankan kelangsungan hidupnya, memajukan serta mengembangkan usahanya ketingkat yang lebih tinggi. Untuk itu setiap perusahaan harus membuat keputusan bisnis yang baik. Keputusan bisnis tersebut dapat dilakukan dengan menggunakan sistem internal control untuk mengarahkan kegiatan operasional perusahaan. Pengendalian internal berperan penting dalam perusahaan karena semakin besar dan banyaknya operasi pada perusahaan, juga karena pengendalian internal merupakan suatu metode dan prosedur yang secara langsung atau tidak langsung yang dapat meminimalkan segala penyelewengan yang mungkin dapat merugikan perusahaan. Tujuan pengendalian internal ini dapat tercapai jika unsurunsur pengendalian internal perusahaan itu terpenuhi dengan baik. Diperlukan juga bagian tertentu bertugas untuk mengawasi dan mengevaluasi efektivitas dan efisiensi dalam pengendalian internal. Untuk menunjang keefektivan suatu pengendalian internal maka salah satu unsur yang penting adalah adanya suatu bagian dalam perusahaan yang bertugas menilai kelayakan dan keefektivan pengendalian internal yang ada dan menilai kualitas kegiatan yang telah dijalankan perusahaan. Dalam penelitian ini, bagian yang juga ikut mengawasi kegiatan perusahaan adalah bagian TAFIC, karena pada bagian ini kita bisa mengetahui segala transaksi yang terjadi di toko, dan biaya apa yang nantinya akan terjadi.

Penyebab kelima yaitu kompetensi sumber daya manusia. Kurangnya karyawan yang memiliki kemampuan dalam menjalankan dan/atau melaksanakan tugas, tanggungjawab dan perannya yang menyebabkan kurang maksimalnya pengelolaan (manajemen) perusahaan, baik dilihat dari tingkat pendidikan, pengalaman kerja maupun skill yang dimiliki para karyawan. Butuhnya pembaharuan dibidang struktur organisasi dan peraturan ketenangakerjaan yang terhambat karena pelannya wewenang atau regulasi yang ada, serta adanya oknum-oknum karyawan yang salah dalam menggunakan wewenangnya untuk kepentingan pribadi dan/atau kelompoknya. Adanya masalah ketersediaan informasi karena belum terbangunnya komunikasi yang maksimal (miskomunikasi) antar karyawan dan belum adanya sinkronisasi antar bagian yang ada dalam perusahaan. Adanya kendala sumber daya yang terbagi atas 2 (dua) faktor yaitu sumber daya manusia dan penyalahgunaan wewenang. Keberhasilan proses implementasi kebijakan sangat tergantung dari kemampuan memanfaatkan sumber daya yang tersedia. Manusia merupakan sumber daya yang terpenting dalam menentukan suatu keberhasilan proses implementasi. Tetapi ketika kompetensi dan kapabilitas dari sumber-sumber daya itu nihil, maka kinerja karyawan sangat sulit untuk diharapkan seperti halnya mengenai integritas. Berdasarkan data mengenai penilaian terhadap crew toko atas keluhan pelanggan dan pengetahuan atas produk yamg dijual, penilaian terhadap karyawan cabang Manado sangat rendah yaitu hanya $62,61 \%$ saja, diikuti dengan Kotabumi, Plumbon, Batam, Cikokol, yang memiliki nilai $65 \%$. Adapun cabang yang nilainya tertinggi adalah Medan dengan 90,53\%, dan diikuti dengan cabang Makassar dan Bogor dengan nilai $82 \%$ dan $81 \%$. Penilaian tersebut dilihat dari berapa banyak keluhan pelanggan yang masuk ke pusat costumer care Alfamart, dan pengetahuan atas knowledge product yang diketahui oleh para karyawan tersebut. Keluhan pelanggan tersebut dikategorikan, dan yang paling banyak adalah mengenai masalah kompetensi integritas dan knowledge.Integritas adalah suatu konsep berkaitan dengan konsistensi dalam tindakan-tindakan, nilai-nilai, metode-metode, ukuranukuran, prinsip-prinsip, ekspektasi-ekspektasi dan berbagai hal yang dihasilkan. Orang berintegritas berarti memiliki pribadi yang jujur dan memiliki karakter kuat. Hidup dalam integritas berarti bahwa kita tidak mempertanyakan diri kita sendiri. Ketika kita mendengarkan hati kita dan melakukan hal yang benar, hidup menjadi sederhana, dan kita hidup dalam damai. Tindakan kita sekarang terbuka untuk dilihat semua orang, dan kita tidak perlu khawatir tentang hal-hal yang kita sembunyikan, 
karena ketika kita memiliki integritas, kita mendapatkan kepercayaan dari orang lain. Adapun tingkat pendidikan terakhir yang ditempuh oleh karyawan Alfamart cabang Manado paling banyak adalah SMA/SMK dengan presentase $92 \%$ atau 2525 orang karyawan. Selanjutnya diikuti oleh 171 orang karyawan memiliki pendidikan terakhir S1 (6\%), dan 40 orang karyawan memiliki pendidikan terakhir D3 (2\%). Dari data ini dapat kita ketahui bahwa karyawan yang banyak di miliki oleh PT Sumber Alfaria Trijaya Tbk adalah yang berlatar belakang SMA, yang kebanyakan dari mereka menjadi Crew di toko dan menjadi pertahanan utama dalam melakukan penjualan di toko. Tidak semua yang berlatar belakang SMA memliki integritas yang buruk, karena ada pula dari crew toko tersebut yang nantinya bisa menjadi seorang pemimpin, dan tidak pula semua yang berlatar belakang S1 berintegritas baik, karena terkadang setiap manusia memiliki kelemahan, seperti adanya penyalahgunaan wewenang, yang biasanya dilakukan oleh seorang pemimpin. Integritas dibutuhkan oleh siapa saja, tidak hanya pemimpin namun juga yang dipimpin. Orang-orang menginginkan jaminan bahwa pemimpin mereka dapat dipercaya jika mereka harus menjadi pengikut-pengikutnya. Mereka merasa yakin bahwa sang pemimpin memperhatikan kepentingan setiap anggota tim dan sang pemimpin harus menaruh kepercayaan bahwa para anggota timnya melakukan tugas tanggung-jawab mereka.

Penyebab keenam adalah persaingan usaha sesama industri. Perkembangan usaha ritel yang semakin pesat dan tumbuhnya pesaing yang bermunculan membuat top management mulai menganalisa risiko yang akan timbul di masa depan. Perusahaan dituntut untuk bekerja secara ekonomis, efisien dan efektif yang akan memungkinkan untuk dapat berkompetisi dengan pesaingnya. Persaingan yang sengit karena kompetitor lebih berani dalam mengambil tindakan untuk membuka toko baru atau lebih cekatan dalam mencari lokasi yang strategis. Seolah dalam sebuah pertandingan, Alfamart dan kompetitornya saling menunjukan kekuatannya untuk merebut hati konsumen. Keberadaan kedua minimarket ini yang kerap berdekatan mengindikasi bahwa persaingan antar keduanya memang cukup ketat, dan kedua minimarket tersebut tidak keberatan saling bersaing dalam wilayah yang sama untuk menunjukan eksistensi masing-masing. Kompetisi merupakan persaingan yang merujuk kepada kata sifat siap bersaing dalam kondisi nyata dari setiap hal atau aktifitas yang dijalani. Ketika kita bersikap kompetitif maka kita memiliki sikap siap serta berani bersaing dengan orang lain. Dalam arti yang positif dan optimis, kompetisi bisa diarahkan pada kesiapan dan kemampuan untuk mencapai kemajuan dan kesejahteraan kita sebagai umat manusia. Kompetisi seperti ini merupakan motivasi diri sekaligus faktor penggali dan pengembang potensi diri dalam menghadapi bentuk-bentuk kompetisi, sehingga kompetisi tidak semata-mata diarahkan untuk mendapatkan kemenangan dan mengalahkan lawan (Saman, 2010).

\section{Upaya yang dilakukan PT Sumber Alfaria Trijaya Tbk Cabang Manado sehingga tidak mengalami kerugian}

Untuk menyelesaikan masalah terkait kerugian yang terjadi, maka upaya yang dilakukan oleh PT Sumber Alfaria Trijaya Tbk Cabang Manado yang pertama yaitu melakukan strategi reward dan punishment. Sebagai bagian dari faktor internal, penghargaan (reward) dan hukuman atau sanksi (punishment) merupakan unsur penting dalam penciptaan tinggi ataupun rendahnya kinerja karyawan. Penghargaan (reward) merupakan salah satu metode yang digunakan dalam memotivasi seseorang untuk melakukan kebaikan dan meningkatkan prestasi kerja atau kinerja. Penghargaan (reward) dapat diartikan sebagai bentuk apresiasi terhadap suatu prestasi tertentu yang diperlihatkan/dimunculkan, baik oleh dan dari perorangan ataupun suatu lembaga yang biasanya diberikan dalam bentuk materi atau ucapan, sehingga pihak manajemen harus memastikan bahwa karyawan mengikuti aturan perusahaan dalam melaksanakan pekerjaan. Tinggi ataupun rendahnya kinerja karyawan tidak hanya dipengaruhi oleh penghargaan (reward), namun terdapat faktor lainnya yaitu hukuman atau sanksi (punishment). Hukuman (punishment) merupakan ancaman hukuman atau hukuman yang bertujuan untuk memperbaiki kinerja karyawan, memelihara peraturan yang berlaku dan memberikan pelajaran kepada karyawan yang melakukan pelanggaran. Dalam konsep manajemen ritel, reward merupakan salah satu alat untuk meningkatkan motivasi kinerja para pegawai. Metode ini bisa mengasosiasikan perbuatan dan kelakuan seseorang dengan perasaan bahagia, senang, dan biasanya akan membuat mereka melakukan suatu perbuatan yang baik secara berulang-ulang. Hal ini seperti yang di kemukakan oleh Davis dan Newstrom (2008: 96) bahwa teori instrumentalitas menunjukkan keyakinan pegawai bahwa ia akan memperoleh suatu imbalan apabila tugas dapat diselesaikan. Dalam hal ini, pegawai melakukan penilaian (judgement) subyektif lainnya tentang kemungkinan bahwa organisasi menghargai prestasi itu dan akan memberikan imbalan jasa. Reward juga bertujuan agar seseorang menjadi semakin giat dalam usaha memperbaiki atau meningkatkan prestasi yang telah 
dicapainya. Manusia selalu mempunyai cita-cita, harapan dan keinginan. Inilah yang dimanfaatkan oleh metode reward. Dengan metode ini, seseorang mengerjakan perbuatan baik atau mencapai suatu prestasi tertentu akan diberikan reward yang menarik sebagai imbalan. Dengan demikian, pegawai akan melakukan perbuatan atau mencapai suatu prestasi agar memperoleh reward tersebut. Menurut Kadarisman (2012:122), indikator reward (penghargaan) adalah Upah, Gaji, Insentif, Tunjangan, Penghargaan Interpersonal, dan Promosi. Menurut Purwanto (2006:186), punishment adalah penderitaan yang diberikan atau ditimbulkan dengan sengaja oleh seseorang sesudah terjadi suatu pelanggaran, kejahatan atau kesalahan. Dalam konteks perusahaan, punishment akan diberikan kepada karyawan yang lalai atau melakukan suatu kesalahan yang merugikan perusahaan. Punishment adalah suatu perbuatan yang kurang menyenangkan, yang berupa hukuman atau sanksi yang diberikan kepada pegawai yang diberikan kepada pegawai secara sadar ketika terjadi pelanggaran agar tidak mengulanginya lagi. Pemberian sanksi atau punishment kapada pegawai sangat sanksi tersebut dapat diberikan berupa teguran, surat peringatan, skrorsing dan bahkan pemberhentian atau pemutusan hubungan kerja. Karyawan yang mendapatkan sanksi atau hukuman biasanya tidak mendapatkan bonus pada bulan terkait, atau bahkan tidak bisa mendapatkan kesempatan promosi jabatan apabila kesalahan yang di lakukan cukup berat. Tujuan dari diterapkannya hukuman atau punishment kepada karyawan adalah menimbulkan rasa yang tidak menyenangkan pada seseorang agar seseorang tersebut tidak membuat suatu hal yang jahat. Jika reward merupakan bentuk yang positif, maka punishment adalah sebagai bentuk yang negatif.

Perbaikan sumber daya manusia. Strategi pengembangan sumber daya manusia perlu dilakukan di era globalisasi seperti sekarang ini. Pengembangan sumber daya manusia dilakukan untuk membentuk personal yang berkualitas dengan keterampilan, kemampuan kerja, dan loyalitas kerja kepada suatu perusahaan ataupun organisasi. Strategi pengembangan sumber daya manusia tidak hanya melalui pendidikan dan pengembangan keterampilan, namun ada banyak cara untuk mengembangkannya. Jajaran karyawan harus komitmen dalam menjalankan kebijakan-kebijakan yang telah ditetapkan. Sikap tegas dan berani, serta disiplin dari pimpinan dalam menindak lanjuti kewenangan yang disalah gunakan oleh oknum-oknum tertentu baik karyawan maupun pihak eksternal. Adanya rekrutmen yang bersifat professional, sehingga mutu dan kualitas sumber daya manusia dapat dipertanggungjawabkan, karena karyawan adalah aset yang perlu diberdayakan, bagian khusus yang mengurusi tentang kepegawaian (personalia) yang benar-benar fokus dibagian tersebut. Yusuf (2015:89) mendefinisikan sumber daya manusia sebagai individu yang merancang dan memproduksi keluaran dalam rangka pencapaian strategi dan tujuan yang telah ditetapkan oleh organisasi. Tanpa individu yang memiliki keahlian atau kompetensi, maka mustahil bagi organisasi untuk mencapai tujuan. Sumber daya manusia inilah yang membuat sumber daya lainnya dapat berjalan.Sumber daya manusia mempunyai peranan sangat penting dalam suatu organisasi. Apalagi dalam menghadapi era global ini, organisasi akan dihadapkan pada kompetensi baik dalam skala nasional maupun internasional. Sumber daya manusia juga merupakan asset terpenting dan berfungsi sebagai modal di dalam suatu organisasi bisnis, modal yang dimaksud disini adalah modal non financial yang dapat dijadikan sebagai potensi yang nyata secara fisik dan non fisik dalam mewujudkan suatu eksistensi organisasi. Peningkatan kualitas efektifitas dan efisiensi kegiatan organisasi tidak hanya tergantung kepada peralatan-peralatan yang terdapat dalam kantor seperti mesin-mesin yang canggih dan modern, modal yang besar, dan adanya kualitas bahan baku yang bermutu. Semua faktor-faktor tersebut tidak berarti sama sekali tanpa adanya dukungan dari sumber daya manusia yang baik dan juga efektif. Perusahaan yang akan sukses adalah perusahaan yang mengerti dan mengetahui bagaimana pentingnya dan upaya-upaya apa saja yang harus dilakukan untuk melaksanakan strategi pengembangan sumber daya manusia dalam organisasinya. Dengan demikian peran sumber daya manusia dalam organisasi sangatlah penting dan sangat berpengaruh besar terhadap jalannya atau lancarnya kegiatan suatu organisasi dalam mencapai tujuannya. Salah satu cara untuk meningkatkan sumber daya manusia secara efektif yaitu dengan motivasi, pelatihan dan pengembangan kerja, kompensasi dan promosi.

Meningkatkan penjualan. Ketika berbicara mengenai usaha retail, ada beragam jenis usaha yang bisa dipilih. Bisnis franchise atau bisnis waralaba merupakan sebuah metode membuka bisnis dengan nama, merek dagang hingga produk dan bahan dari bisnis yang sudah ada, dalam hal ini merek dagang Alfamart. Secara umum waralaba atau franchise merupakan cara bisnis dengan memperluas dan mendistribusikan barang atau jasa dengan lisensi dagang. Pemegang franchise misalkan Anda, membayar biaya awal dan royalti kepada pemilik merek franchise untuk menggunakan merek dagang, logo, sistem bisnis waralaba serta hak untuk menjual produk dan mendapat dukungan dari pemilik 
franchise. Untuk meminimalisir kerugian, perusahaan harus meningkatkan penjualannya, untuk dapat menambah penghasilan perusahaan juga dapat memperbanyak toko franchise. Perkembangan minat masyarakat terhadap investasi dibidang bisnis, secara tidak langsung mendorong pertumbuhan franchise yang ada di Indonesia juga semakin meningkat. Beragam jenis penawaran investasi melalui kemitraan (franchise) mendapatkan respon yang cukup baik dari para calon investor. Alfamart masih sangat kurang dalam pembukaan toko franchise jika dibandingkan dengan cabang yang lainnya. Toko franchise yang ada di Manado hanya berjumlah 6 toko saja, dan diharapkan adanya peningkatan dalam pencarian investor agar dapat bekerja sama dengan Alfamart. Sistem franchise ini mempunyai keunggulan-keunggulan. Keunggulannya adalah seperti dalam praktek retailing, franchising menawarkan keuntungan untuk memulai suatu bisnis baru dengan cepat berdasar pada suatu merek dagang yang telah terbukti bisnisnya, tidak sama seperti dengan membangun suatu merek dan bisnis baru dari awal mula (Rachmadi, 2017:8).

\section{Penutup}

Kesimpulan dalam penelitian ini adalah: 1) Penyebab kerugian pada PT Sumber Alfaria Trijaya Tbk Cabang Manado yaitu adanya ekspansi, umur perusahaan yang masih baru, adanya fraud, pengendalian internal yang belum memadai, kompetensi sumber daya manusia, dan adanya persaingan usaha sesama industri; 2) upaya yang dilakukan oleh PT Sumber Alfaria Trijaya Tbk Cabang Manado, yaitu mengupayakan strategi reward dan punishment, perbaikan sumber daya manusia, dan meningkatkan penjualan.

Saran yang dapat diberikan dari penelitian ini yaitu: 1) pimpinan Alfamart harus selalu memberikan motivasi dan dukungan penuh kepada seluruh karyawan dan menjaga konsistensi dari penerapan pengembangan sumber daya manusia, bahkan apabila mungkin perusahaan harus dapat menambah beberapa hal baru yang berkaitan dengan penerapan pengembangan sumber daya manusia; 2) sumber daya manusia pada bisnis ritel sebaiknya diatur dan dikelola agar supaya karyawan lebih memperhatikan pelayanan terhadap konsumen, serta memperhatikan kelengkapan produk yang akan dipasarkan. Pelayanan terhadap pelanggan juga perlu untuk ditingkatkan, agar pelanggan merasa nyaman berbelanja dan untuk selanjutnya memilih untuk tetap berbelanja di Alfamart; 3) untuk penelitian selanjutnya hal yang bisa dilakukan adalah menambah key informant dan menambah waktu penelitian, atau lebih meneliti secara detail satu per satu tentang penyebab kerugian yang terjadi.

\section{Daftar Pustaka}

Albrecht, W. S., C. O. Albrecht and C. C. Zimbelman. 2011. Fraud Examination, $4^{\text {th }}$ Edition. Journal. Cengage Learning: Mason, Ohio. Vol. 9, No. 6, 34-53.

Creswell, John W. 2010. Terjemahan: Research Design Pendekatan Kualitatif, Kuantitatif dan Mixed. Pustaka Pelajar. Yogyakarta.

Davis, Keith dan John W. Newstrom. 2008. Perilaku Dalam Organisasi. Jakarta: Erlangga.

Endraswara, Suwardi. 2013. Metodologi Penelitian Sastra. Yogyakarta: CAPS (Center for Academic Publishing Service).

Harry. 2011. Akuntansi Perusahaan Dagang dan Jasa. Bandung: Alfabeta.

Heikal, M., M. Khaddafi, dan A. Ummah. 2014. Influence Analysis of Return on Assets, Return on Equity, Net Profit Margin, Debt to Equity Ratio, and Current Ratio, Against Corporate Profit Growth In Automotive In Indonesia Stock Exchange. Internasional Journal of Academic Research in Business and Social Sciences. Vol 4, No. 12.

Kadarisman. 2012. Manajemen Kompensasi. Jakarta: Raja grafindo Persada.

Kusuma, Jaya. 2017. Detik.com. 9 Agustus 2017.Hingga Juni 2017, Penjualan Ritel Cuma Tumbuh 3,7\%. Narasumber Tutum Rahanta (Wakil Ketua Aprindo).

Martono, Harjito Agus. 2010. Manajemen Keuangan (Edisi 3). Yogyakarta: Ekonisia.

Peraturan Presiden No. 112 Tahun 2007 tentang Penataan dan Pembinaan Pasar Tradisional, Pusat Perbelanjaan dan Toko Modern.

Peraturan Menteri Perdagangan No. 53 Tahun 2008 tentang Pedoman Penataan dan Pembinaan Pasar Tradisional, Pusat Perbelanjaan dan Toko Modern.

Purwanto, M. Ngalim. 2006. Ilmu Pendidikan Teoritis Dan Praktis. Bandung: Remaja Rosdakarya.

Prayogo, Cahyo. Warta Ekonomi. 2017. Quo Vadis Industri Ritel Indonesia. Narasumber Roy Nicholas Mandey (Ketua Umum Aprindo).

Rachmadi, Bambang N. 2017. Franchising The most Practical and Excellent Way of. Succeeding. Cetakan kedua. Jakarta: Gramedia Pustaka Utama. 
Riyanto, Bambang. 2010. Dasar-Dasar Pembelanjaan Perusahaan, Edisi Keempat,Cetakan Ketujuh. Yogyakarta: BPFE.

Saman, Muhammad. 2010. Persaingan Industri PT. Pancanata Centralindo (Perspektif Etika Bisnis Islam). Jurnal. Vol. 3, No. 19, 1-25.

Sugiyono. 2015. Metodologi Penelitian Kuantitatif, Kualitatif dan Kombinasi (mixed methods). Bandung: Alfabeta.

Wimbush, J.C. dan Dalton, D.R., 1997. Base Rate for Employee Theft: Convergence of Multiple Methods, Journal of Applied Psychology. Vol 82, No. 5, 756-763.

Yusuf Zainal, Abidin. 2015. Manajemen Komunikasi Filosofi, Konsep, dan Aplikasi. Bandung:CV Pustaka Setia. 